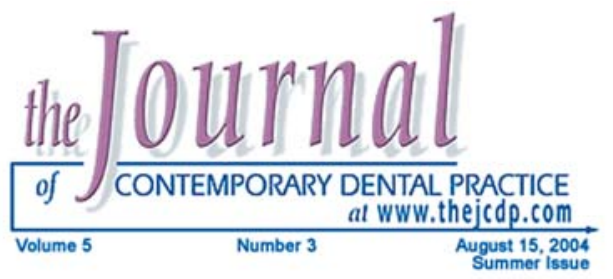

\title{
The Effect of Different Lower Third Molar Conditions on the Re-Crowding of Lower Anterior Teeth in the Absence of Tight Interproximal Contacts One-Year Post Orthodontic Treatment: A Pilot Study
}

\author{
Khalid M. Al-Balkhi, BDS, MSc
}

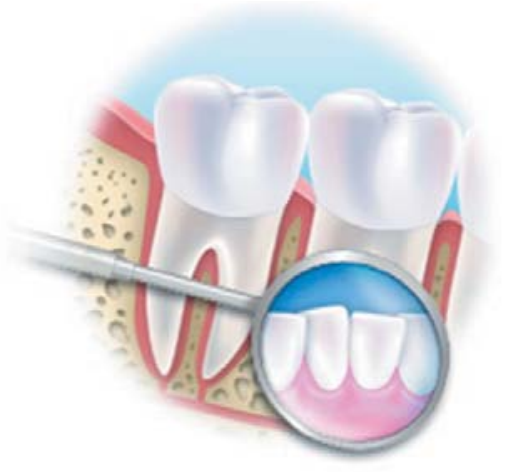

Abstract

The role of lower third molars in lower incisor crowding is a debatable topic. Some believe the presence or eruption of lower third molars is associated with the crowding of mandibular incisors, others negate such association. Thirty-two newly debonded orthodontic patients, with ages ranging from 14-19 years, were randomly selected. No retainers were used for the lower dental arch. Removal of tight interproximal contacts of the lower anterior teeth was created and maintained by periodic abrasive stripping every 2-3 months, if needed. The cases were followed up for one year. Orthopantomographs (OPGs) and study casts were taken at debonding (post-treatment) and at the end of the one year follow up (post retention). Statistical analysis of the lower third molar conditions - erupted, unerupted, or missing with or without sufficient space for their eruption - versus re-crowding of lower incisors was evaluated using Fisher's Exact Test. The results of this pilot study revealed there was no significant correlation between the different conditions of the lower third molars versus lower anterior re-crowding in the absence of tight interproximal incisal contacts; however, a larger sample size is needed to verify such findings.

Keywords: Orthodontics, lower third molars, lower incisors crowding

Citation: Al-Balkhi KM . The Effect of Different Lower Third Molar Conditions on the Re-Crowding of Lower Anterior Teeth in the Absence of Tight Interproximal Contacts One-Year Post Orthodontic Treatment: A Pilot Study. J Contemp Dent Pract 2004 August;(5)3:066-073.

(C) Seer Publishing 
Introduction

The role of third molars in lower incisor crowding has been debated for more than a century. It is often presumed the presence or eruption of lower third molars is associated with crowding of the mandibular incisors. Robinson ${ }^{1}$ incriminated lower third molars in the etiology of lower incisor crowding. Dewey ${ }^{2}$ reported third molars create space to erupt, thereby, causing anterior teeth to crowd. Broadbent ${ }^{3}$ postulated that in the absence of third molars, the dentition could settle distally in response to the forces generated by growth changes or soft tissue pressure. This implies a passive role of third molars in the development of late crowding by resisting those forces. This was supported by Blake and Bibby. ${ }^{4}$ A survey by Laskin ${ }^{5}$ which included a large number of orthodontists and oral surgeons showed $65 \%$ of both groups believed in a cause-effect relationship between lower third molars and lower incisor crowding. ${ }^{5}$

On the other hand, Ades et al. ${ }^{6}$ found there was no significant difference in incisor crowding in groups with impacted, missing, or extracted third molars. Richardson ${ }^{7,8}$ reported a significant forward movement of first molars between the ages of 13 and 17 years, which correlated with an increase in lower arch crowding that occurred during the same period. However, there was no difference in the forward movement of the first molars in cases with or without impacted lower third molars. This was supported by Richardson, in a study on 42 patients from a Belfast growth group. ${ }^{9}$

The aim of the present study was to investigate the role of third molars in lower anterior re-crowding in the absence of tight interproximal contacts.

\section{Methods and Materials}

Thirty-two newly debonded orthodontic patients, ages ranging from 14-19 years, were randomly selected from an orthodontic clinic. The cases were treated with four premolar extractions using 022 straight wire mechanotherapy. The average treatment time was $24 \pm 8$ months. At debonding, an orthopantomograph (OPG) was taken and an orthodontic study cast was made for each case (post-treatment). The cases were followed up for one year without any retainer in the lower arch. On the other hand, a removable Hawley retainer was used in the upper arch.
The cases were debonded with no crowding within the lower anterior teeth. Tight interproximal contacts of upper and lower anterior teeth were relived by using abrasive strips every $2-3$ months. At the end of the one year follow up, another OPG was taken and another orthodontic study cast was made for each case (postretention).

\section{Cast Assessment}

At debonding (post-treatment) and at the end of one year follow up (post-retention), crowding or insufficient arch length of the lower anterior teeth were evaluated from the orthodontic casts using the brass wire technique. The brass wire contoured over the buccal cusps and incisal tips of the lower anterior teeth, from distal to distal inter-canine distance ${ }^{10}$ (Nance, 1947).

\section{Panoramic Assessment}

Post-treatment and post-retention, panoramic radiographs were used to evaluate third molar conditions. The presence, absence, sufficient, or insufficient space for the unerupted lower third molars were determined according to the Pell and Gregory Classification I, II, and III. ${ }^{11}$ In Class Ithe unerupted third molar is anterior to the mandibular ramus, thus, having sufficient space to erupt. In Class II and III the ramus is situated over half of the crown of the unerupted lower third molar, and completely covering the lower third molar crown, respectively.

\section{Statistical Analysis}

Fisher's Exact Test was used to assess the significant differences between re-crowding and non-crowding of the lower anterior teeth within the different conditions of lower third molars.

\section{Results}

At the end of the one year follow up, five out of the 32 cases showed incisal re-crowding of an average of $0.89 \mathrm{~mm} \pm 1.39$, while the remaining 27 cases were well aligned with zero crowding. Those five cases expressed some overlapping of the incisors, while still maintaining absence of tight interproximal contacts.

There was no significant correlation between re-crowded and uncrowded lower incisors with the different conditions of lower third molars in regard to their presence as erupted, missing, or 
unerupted with or without sufficient space for their eruption. (Tables 1 and 2)

Out of the 32 cases (100\%), two cases $(6.25 \%)$ had erupted third molars. One case (50\%) showed incisor re-crowding and the other (50\%) did not. Seven cases (21.88\%) out of the total 32 cases had missing lower third molars. One case $(14.29 \%)$ showed no crowding.

In the remaining 23 cases $(71.87 \%)$, six $(26.09 \%)$ had sufficient space for the eruption of lower third molars. One of those six cases (16.67\%) showed re-crowding and five (83.33\%) did not show crowding. On the other hand, 17 cases $(73.91 \%)$ out of the 23 non-erupted lower third molars had insufficient space for their eruption. Two cases $(11.76 \%)$ showed re-crowding and $15(88.24 \%)$ did not show crowding. (Figure 1)

\section{Discussion}

Whether lower third molars were missing or unerupted with sufficient or insufficient space for their eruption, $85.71 \%, 83.33 \%$, and $88.24 \%$

Table 1. Distribution and percentages between non-crowded and recrowded lower incisors among erupted and missing lower third molars.

\begin{tabular}{|c|c|c|c|c|}
\hline \multirow{2}{*}{\multicolumn{2}{|c|}{ Lower Third Molar }} & \multicolumn{2}{|c|}{ No. \& percentage of cases } & \multirow{3}{*}{$\begin{array}{r}\text { Total } \\
2 \\
100.0 \% \\
22.22 \%\end{array}$} \\
\hline & & Non-crowded & Recrowded & \\
\hline Erupted & $\begin{array}{l}\text { Count } \\
\% \text { within } 3^{\text {rd }} \text { molar condition } \\
\% \text { within recrowded/non-crowded }\end{array}$ & $\begin{array}{r}1 \\
50.0 \% \\
14.29 \%\end{array}$ & $\begin{array}{r}1 \\
50.0 \% \\
50.0 \%\end{array}$ & \\
\hline Missing & $\begin{array}{l}\text { Count } \\
\% \text { within } 3^{\text {rd }} \text { molar condition } \\
\% \text { within recrowded/non-crowded }\end{array}$ & $\begin{array}{r}6 \\
85.71 \% \\
85.71 \%\end{array}$ & $\begin{array}{r}1 \\
14.29 \% \\
50.0 \%\end{array}$ & $\begin{array}{r}7 \\
100.0 \% \\
77.78 \%\end{array}$ \\
\hline Total & $\begin{array}{l}\text { Count } \\
\% \text { within } 3^{\text {rd }} \text { molar condition } \\
\% \text { within recrowded/non-crowded }\end{array}$ & $\begin{array}{r}7 \\
77.78 \% \\
100.0 \%\end{array}$ & $\begin{array}{r}2 \\
22.22 \% \\
100.0 \%\end{array}$ & $\begin{array}{r}9 \\
100.0 \% \\
100.0 \%\end{array}$ \\
\hline
\end{tabular}

$P=0.417$

Table 2. Distribution and percentages between non-crowded and recrowded lower incisors among non-erupted lower third molars with sufficient and insufficient space.

\begin{tabular}{|c|c|c|c|c|}
\hline \multirow{2}{*}{\multicolumn{2}{|c|}{ Lower Third Molar }} & \multicolumn{2}{|c|}{ No. \& percentage of cases } & \multirow{3}{*}{$\begin{array}{r}\text { Total } \\
6 \\
100.0 \% \\
26.09 \%\end{array}$} \\
\hline & & Non-crowded & Recrowded & \\
\hline $\begin{array}{l}\text { With sufficient } \\
\text { space }\end{array}$ & $\begin{array}{l}\text { Count } \\
\% \text { within } 3^{\text {rd }} \text { molar condition } \\
\% \text { within recrowded/non-crowded }\end{array}$ & $\begin{array}{r}5 \\
83.33 \% \\
25.0 \%\end{array}$ & $\begin{array}{r}1 \\
16.67 \% \\
33.33 \%\end{array}$ & \\
\hline $\begin{array}{l}\text { With insufficient } \\
\text { space }\end{array}$ & $\begin{array}{l}\text { Count } \\
\% \text { within } 3^{\text {rd }} \text { molar condition } \\
\% \text { within recrowded/non-crowded }\end{array}$ & $\begin{array}{r}15 \\
88.24 \% \\
75.0 \%\end{array}$ & $\begin{array}{r}2 \\
11.76 \% \\
66.67 \%\end{array}$ & $\begin{array}{r}17 \\
100.0 \% \\
73.91 \%\end{array}$ \\
\hline Total & $\begin{array}{l}\text { Count } \\
\% \text { within } 3^{\text {rd }} \text { molar condition } \\
\% \text { within recrowded/non-crowded }\end{array}$ & $\begin{array}{r}20 \\
86.96 \% \\
100.0 \%\end{array}$ & $\begin{array}{r}3 \\
13.04 \% \\
100.0 \%\end{array}$ & $\begin{array}{r}23 \\
100.0 \% \\
100.0 \%\end{array}$ \\
\hline
\end{tabular}

$P=0.616$ 


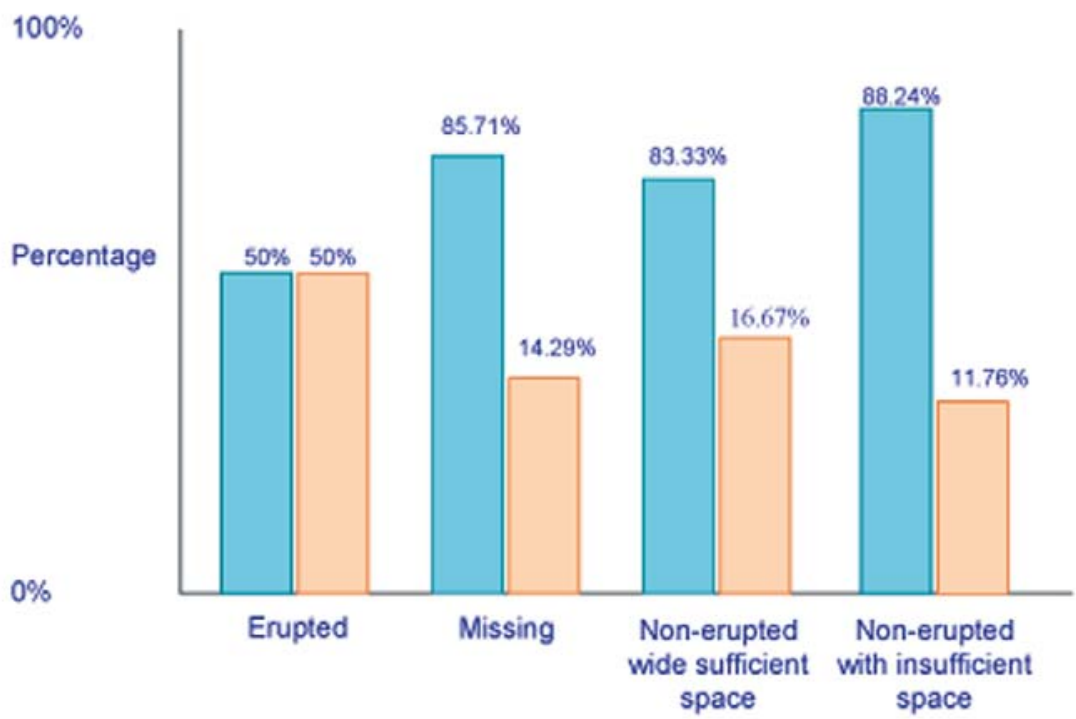

Lower third molar condition

Figure 1. The lower third molars' conditions and percentages among recrowded and non-crowded cases at the end of the one year follow up.

showed no re-crowding of lower anterior incisors, respectively. Due to the small sample size in this pilot study the Fisher's Exact Test was used rather than the usual Chi-square Test. No significant correlation between re-crowding and uncrowding of the lower anterior teeth within the different conditions of lower third molars was found. A larger sample size is needed to verify such findings. It will also be beneficial to evaluate the different lower third conditions in the presence of normal interproximal contact [which may include tight contacts] and then compare such findings of the two studies.

Kaplan $^{12}$ with no interproximal reduction found there was no significant difference between the different groups of third molars, whether erupted, impacted, or present. This indicates the presence of third molars has no effect in inducing lower anterior crowding. This finding was supported by Richardson ${ }^{7}$, Kahl-Nieke $^{13}$, Bishara and Andresson. ${ }^{14}$
Vasir and Robinson ${ }^{15}$ reported that lower anterior crowding seen with erupting or erupted lower third molars has a multi-factorial etiology. These factors include: (1) anterior growth and remodeling of the mandible; (2) pre-existing tooth-tissue discrepancy; (3) mesial drift; (4) anterior component of force of the occlusion; (5) soft tissue maturation; (6) tooth size and shape; (7) lack of attrition; (8) difference between the evolutionary reduction of tooth size and jaw size, and last (9) the mandibular third molar. The findings of our study seems to support reports indicating lower third molars do not have that great of influence on lower incisor recrowding.

\section{Conclusion}

This pilot study seems to support the opinion the role of the lower third molars is not a significant factor in causing lower anterior re-crowding in the absence of tight interproximal contacts. However, a larger sample size is needed to verify such findings. 


\section{References}

1. Robinson J. The causes of irregularities of the teeth. Dental Review. In: Weinberger B.W. (1926) Orthodontics: An Orthodontics historical review of its origin and evolution. Vol. 1, C.V. Mosby Company, 325.

2. Dewey M. Third molar in relations to malocclusion inifo. J Orthod. 1917;3:529.

3. Broadbent BH. Orthognathic development of occlusion. Angle Orthod. 1941;11:223-41.

4. Blake M, Bibby K. Retention and stability: a review of the literature. Am J Orthod Dentofacial Orthop. 1998 Sep;114(3):299-306. Review.

5. Laskin DM. Evaluation of the third molar problem. J Am Dent Assoc. 1971 Apr;82(4):824-8. No abstract available.

6. Ades AG, Joondeph DR, Little RM, et. al. A long-term study of the relationship of third molars to changes in the mandibular dental arch. Am J Orthod Dentofacial Orthop. 1990 Apr;97(4):323-35.

7. Richardson ME. The etiology of lower incisor crowding. J Irish Dent Assoc. 1980;26-31.

8. Richardson ME. Late lower arch crowding in relation to primary crowding. Angle Orthod. 1982 Oct;52(4):300-12. No abstract available.

9. Richardson ME. Late lower arch crowding in relation to skeletal and dental morphology and growth changes. Br J Orthod. 1996 Aug;23(3):249-54.

10. Nance HN. The limitations of orthodontic treatment I and II. Am J Orthod. 1947;33:177, 253.

11. Waite PD, Reynolds RR. Surgical management of impacted third molars. Semin Orthod. 1998 Jun;4(2):113-23. Review.

12. Kaplan RG. Clinical experiences with circumferential supracrestal fiberotomy. Am J Orthod. 1976 Aug;70(2):146-53.

13. Kahl-Nieke B, Fischbach $\mathrm{H}$, Schwarze $\mathrm{CW}$. Post-retention crowding and incisor irregularity: a longterm follow-up evaluation of stability and relapse. Br J Orthod. 1995 Aug;22(3):249-57.

14. Bishara S, Adreasen G. Third molars: a review. Am J Orthod. 1983 Feb;83(2):131-7.

15. Vasir NS, Robinson RJ. The mandibular third molar and late crowding of the mandibular incisors--a review. Br J Orthod. 1991 Feb;18(1):59-66. Review.

\section{About the Author}

\section{Khalid M. AI-Balkhi, BDS, MSc}

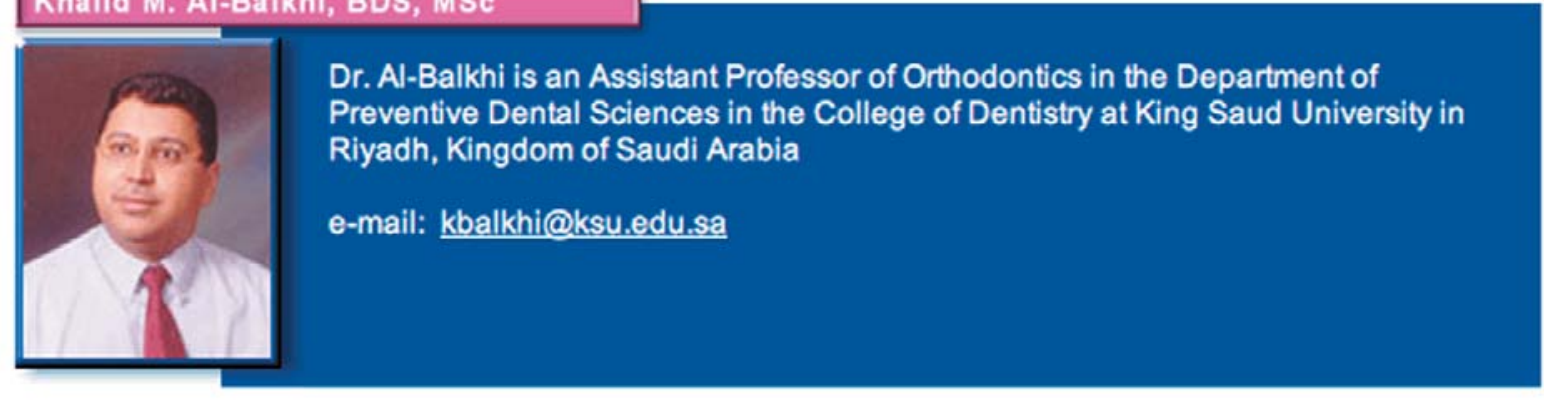

\section{Acknowledgements}

The author would like to acknowledge and express his appreciation to Dr. Basma Al-Maghlouth, Dr. Hayder Hashim, and Mrs. Elizabeth Posadas for their valuable assistance with this study. 